\title{
Distribution and structure of the southernmost Caribbean coral reefs: Golfo de Urabá, Colombia*
}

\author{
JUAN M. DÍAZ1', GUILLERMO DÍAZ-PULIDO ${ }^{1,2}$ and JUAN A. SÁNCHEZ ${ }^{1,3}$ \\ ${ }^{1}$ Instituto de Investigaciones Marinas y Costeras, INVEMAR, A.A. 1016, Santa Marta, Colombia. \\ E-mail: jmdiaz@invemar.org.co. Fax: +57-54-214413 \\ ${ }^{2}$ Present address: Department of Tropical Plant Sciences \& CRC: Reef Research, James Cook University, \\ Townsville, Qld 4811, Australia. \\ ${ }^{3}$ Present address: Department of Biological Sciences, University at Buffalo (State University of New York), \\ 109 Cooke Hall, Buffalo, NY 14260, USA.
}

\begin{abstract}
SUMMARY: The Gulf of Urabá represents the southernmost portion of the Caribbean Sea. Due to the large amounts of sediment and freshwater discharged by the Atrato river and several minor streams, water conditions in the area are far from being optimal for coral settlement and growth. However, fringing and patch reefs are developed along the rocky shores of the northwest margin of the Gulf. Based on field observations performed at 44 sites (12 of them assessed quantitatively), interpretation of air photography of the area and depth profiles, the distribution, structure and zonation of the reefs are described. Classification analysis of the 12 sample sites yielded four coral assemblages: Diploria strigosa, crustose algae, Siderastrea siderea, Agaricia spp., and mixed massive corals. Other two assemblages, dominated respectively by Millepora complanata and thickets of Acropora palmata were noticed during reconnaissance dives. The distribution of these zones within the reef seems likely to be mainly controlled by wave exposure, bottom topography, sedimentation, and light penetration. Reef development, coral diversity and live coral cover increase along the coast in a SE-NW direction, with an evident maximum near to the cove of Sapzurro, suggesting an overall improvement of conditions for coral growth and settlement in that direction. A total of 33 species of hard corals were recorded during the survey. It is apparent that the live coral cover, particularly of foliose and branching species, has notably declined recently.
\end{abstract}

Key words: coral reefs, coral assemblages, Scleractinia, Colombia, Caribbean Sea.

\section{INTRODUCTION}

The Golfo de Urabá, near the Colombia-Panama border, is a N-S embayment, roughly $85 \mathrm{~km}$ long and $15-30 \mathrm{~km}$ wide that represents the southernmost portion of the Caribbean Sea (Fig. 1). The surrounding terrestrial realm, made up predominantly of rain forests and swamps, represents the northern outposts of the Chocó biodiversity centre (cf. Gentry, 1986). Geologically, the Golfo de Urabá corresponds to a

\footnotetext{
*Received May 25, 1999. Accepted March 14, 2000.
}

true depression, the Bolívar Geosyncline, which extends to the south as far as the Gulf of Guayaquil off Ecuador (Haffer, 1970).

The waters in the Golfo de Urabá are highly influenced by terrestrial runoff due to large amounts of sediment and freshwater discharged by the Atrato river into the southern part of the Gulf as well as by several minor streams draining the eastern watersheds of the Darién Massif (Zeigler and Athearn, 1971). Annual precipitation in the Urabá region is regular, with values above $3000 \mathrm{~mm}$ (Haffer, 1970). Although most of the coasts surrounding the gulf are 


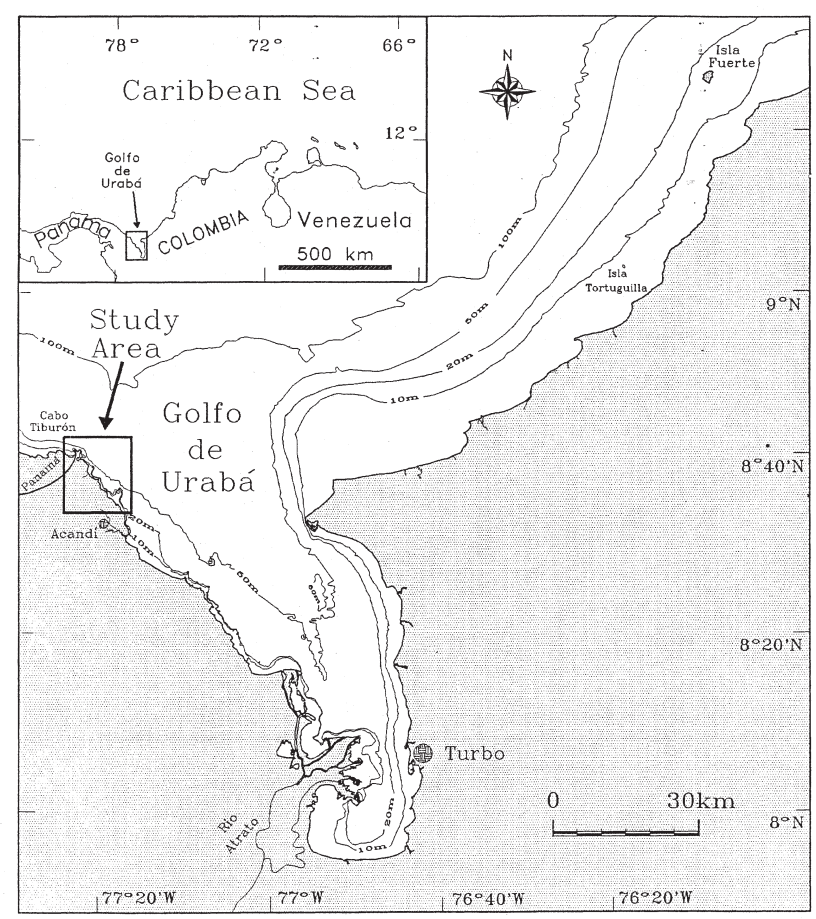

FIG. 1. - Location of the Golfo de Urabá and the study area in the Caribbean Sea; insert map represents the area shown in Figure 2.

dominated by low alluvial plains with swamps and mangroves, a rugged basalt range, 100 to $300 \mathrm{~m}$ in elevation and covered by tropical rain forest, forms the northwestern shore of the Gulf. The shore forms steep rocky slopes, which plunge to depths of 15 to $30 \mathrm{~m}$ before flattening out to muddy, sand flats. Cliffs are interspersed by pocket beaches and coves, and several small islands dot the coastal waters. A rough sea beats the rocky shore during the trade wind season from December to March.

Inventories of the marine biota include those by Sánchez and Ortiz (1992) on the black corals, Werding (1978) and Campos and Manjarrés (1988) on the Crustacea, Acero and Garzón (1987) on the fish fauna and Bula-Meyer and Schnetter (1988) on the benthic algae. Werding and Manjarrés (1978) briefly described the coral communities and other littoral habitats in this area in an unpublished report. They included a checklist containing two milleporids, one stylasterid and 25 scleractinian coral species or morphotypes. However, no attempts were made to comprehensively describe the zonation and distribution of coral communities and other marine habitats. Prahl and Erhardt (1985) and Wells (1988) recently summarized some of their observations but with little new information. No further published information does yet exist about the coral communities and reef structures of this area. The purpose of this paper is to give a detailed description of the gross morphology and community structure of the coral reefs of the Golfo de Urabá.

\section{METHODS}

A preliminary photo-interpretation of geomorphological and ecological features of the northwestern coast of the Golfo de Urabá was done using panchromatic air photography taken in 1975 by the Colombian Geographical Institute (Instituto Geográfico "Agustín Codazzi”). These photographs, with a scale of approximately 1:10,000 were used to draw preliminary maps of the littoral habitats. These maps as well as the only available information on the general distribution of corals in this area (Werding and Manjarrés, 1978) were used as background for field surveillance.

In September 1995, a total of five days were spent in the area making observations and taking samples. Rapid assessments of bottom features for habitat mapping purposes were performed at 32 check points from the surface, or by either free-diving or SCUBA diving to depths of 3 to $25 \mathrm{~m}$. In 12 additional sampling stations by SCUBA diving (Fig. 2 ), percent cover of substrates, coral species, gorgonians, sponges, algal genera and functional groups, and other discernible sessile organisms were

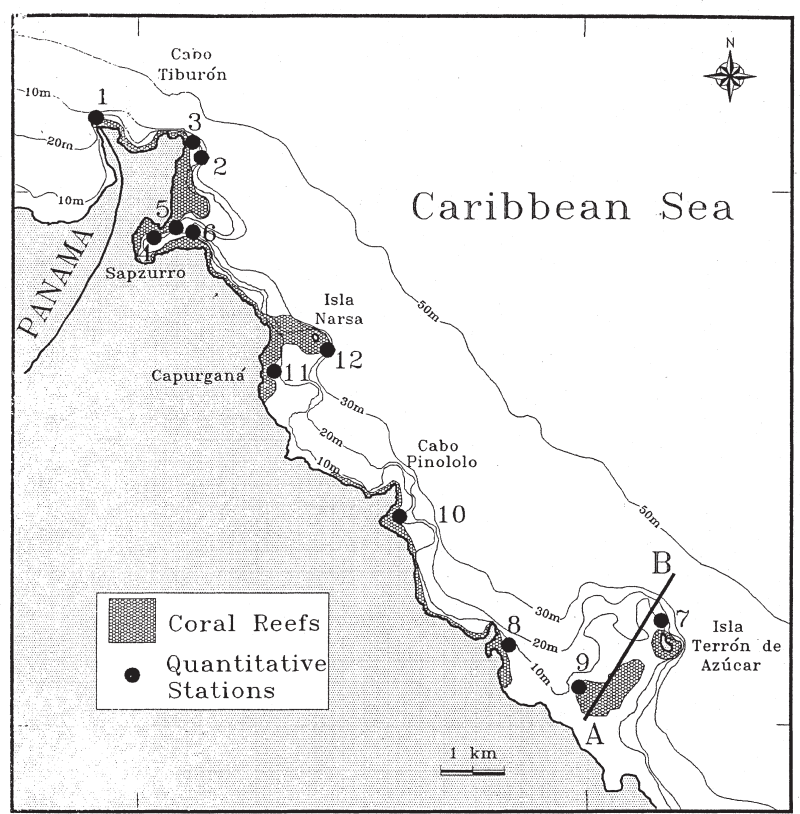

FIG. 2. - Northwestern part of the Golfo de Urabá showing the distribution of hard bottoms with coral cover and the location of sampling stations. Straight line A-B marks the location of the schematic profile of Figure 7. 
determined employing three $10 \mathrm{~m}$ video-transects per station. Transects were placed in areas of maximum coral cover (usually more than $20 \%$ based on visual estimates). Depth, wave regime, direction of currents, dimensions and distribution patterns of the reef structures were noted as well. The sites were chosen to represent the patterns of hard bottom habitats which were previously recognized in the aerial photographs and during field reconnaissance. The accurate geographical placement of the stations within a radius of about $30 \mathrm{~m}$ was determined with the aid of a portable GPS device. Complementary depth profiles were recorded with an echosounder (Furuno ${ }^{\circledR}, 28 \mathrm{khz}$ ) along transects navigated aboard the R/V Ancón of the Instituto de Investigaciones Marinas y Costeras, INVEMAR (Santa Marta, Colombia).

Percent cover data were averaged by station and later classified to discriminate stations with similar composition (i.e. assemblages) and to infer spatial patterns of the structure of the coral reef community. We employed a cluster analysis (Bray-Curtis dissimilarity index, UPGMA, arcsine transformation) on the organisms covering the substrate using a stations matrix to accomplish this. Habitat classification and terminology vary considerably among authors, and the terms used here to define coral reef assemblages and zonation are based on the dominating macrobiota (by relative cover) or substrate features, as has been done elsewhere for reef environ- ments (see Duyl, 1985; Sánchez 1995; Díaz et al., 1996a,b). General bottom topography and habitat distribution maps were drawn combining photo-patterns, field notes, depth profiles, and topographic information inferred from the nautical charts of the area (U.S. DMA No. 5694 and Col 295).

\section{RESULTS}

A calcareous terrace fringes almost the entire coastline where rocky cliffs plunge directly into the sea from about latitude $8^{\circ} 35^{\prime} \mathrm{N}$ northwestward to the Colombia-Panama border at Cabo Tiburón $\left(8^{\circ}\right.$ $41^{\prime} \mathrm{N}$ ) and beyond. Such a terrace also surrounds the small, rocky offshore islets Isla Narsa and Terrón de Azúcar as well (Fig. 2). It descends mostly at low angle (5 to 15 degrees) to a depth of about $4 \mathrm{~m}$ where a topographical break gives way to a more inclined slope that extends down to depths of nearly $20 \mathrm{~m}$ in some locations. Although the highly abrasive conditions have seemingly limited the settlement and growth of hermatypic biota along the most part of the terrace, low relief calcareous, ridge-like structures, with a perpendicular layout to the predominant wave trend, insinuate at some places. Moreover, in several sites, like at the NW margin of the embayment of the village of Capurganá and near the entrance to the cove of Sapzurro, the terrace appears overlayed by coral framework, becomes

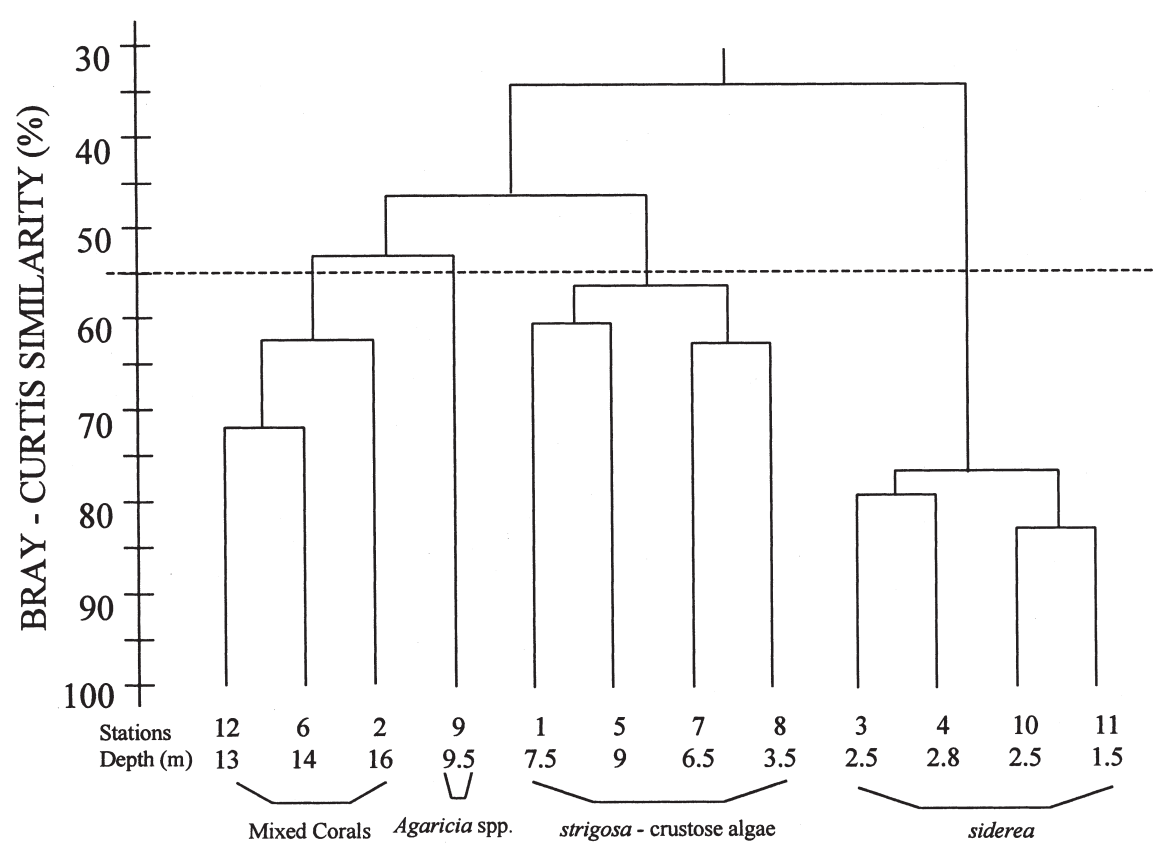

FIG. 3. - Affinity dendrogram of the 12 sampling stations applying the Bray-Curtis dissimilarity index, (UPGMA, arcsine transformation). 
TABLE 1. - Percent cover on hard substrate, excluding sand (minimum and maximum) of species and categories of reef organisms in the four coral assemblages defined by cluster analysis.

\begin{tabular}{|c|c|c|c|c|}
\hline $\begin{array}{l}\text { Assemblages } \\
\text { Stations } \\
\text { Depth range (m) }\end{array}$ & $\begin{array}{c}\text { Mixed corals } \\
12,6,2 \\
13-16\end{array}$ & $\begin{array}{c}\text { Agaricia spp. } \\
9 \\
10\end{array}$ & $\begin{array}{c}\text { strigosa-crustose algae } \\
8,1,7,5 \\
3.5-9\end{array}$ & $\begin{array}{c}\text { siderea } \\
11,3,10,4 \\
1.5-2.8\end{array}$ \\
\hline Millepora alcicornis & _ & _ & $0.2(0-0.8)$ & - \\
\hline Millepora spp. & $0.1(0-0.4)$ & - & $1.1(0-3.2)$ & $1.6(0-3.7)$ \\
\hline Acropora cervicornis & $0.1(0-0.4)$ & - & - & - \\
\hline Acropora palmata & & - & $1.2(0-4.2)$ & - \\
\hline Agaricia agaricites & $3.3(1.3-5.9)$ & 30.1 & $1.1(0.1-2.2)$ & - \\
\hline Agaricia tenuifolia & - & - & $0.3(0-0.7)$ & $0.1(0-0.1)$ \\
\hline Colpophylia natans & $7.3(3-12.6)$ & 2.4 & $0.8(0-3.2)$ & - \\
\hline Dichocoenia stokesi & $0.4(0-0.7)$ & - & - & - \\
\hline Diploria clivosa & - & - & $1.1(0-2.3)$ & - \\
\hline Diploria labryntiformis & $0.2(0-0.5)$ & - & $<0.1(0-0.1)$ & - \\
\hline Diploria strigosa & $0.9(0-1.7)$ & - & $13.6(9.8-16.9)$ & $0.2(0-0.2)$ \\
\hline Favia fragum & - & - & - & $<0.1(0-1.0)$ \\
\hline Helioseris cucullata & $3.2(1.3-4.7)$ & 0.8 & - & - \\
\hline Madracis decactis & $0.1(0-0.3)$ & - & $0.2(0-0.7)$ & - \\
\hline Meandrina meandrites & $1.5(0.2-2.6)$ & - & $1.1(0-4.5)$ & - \\
\hline Montastraea cavernosa & $14.7(2-25.4)$ & - & $4.1(0-10.8)$ & - \\
\hline Montastraea faveolata & - & - & $0.7(0-1.9)$ & - \\
\hline Montastraea franksi & $11.9(0.7-25.3)$ & - & $0.1(0-0.2)$ & - \\
\hline Porites astreoides & $3.9(1.7-5.6)$ & 0.2 & $2.9(2-3.7)$ & - \\
\hline Porites porites & $0.8(0-2.5)$ & - & $0.1(0-0.3)$ & $3.3(0.1-3.3)$ \\
\hline Siderastrea radians & - & - & - & $0.1(0-0.3)$ \\
\hline Siderastrea siderea & $0.5(0-1.4)$ & - & $1.4(0.3-3.1)$ & $49.6(35.1-61.4)$ \\
\hline Stephanocoenia intersepta & $0.6(0-1.8)$ & - & - & - \\
\hline Total coral cover & $49.6(46.6-52.2)$ & 33.4 & $30.0(22.0-40.9)$ & $58.4(35.3-69.1)$ \\
\hline Blue-green algae & $2.7(0.4-6.4)$ & 16.9 & $3.2(0-12.6)$ & - \\
\hline Algal turfs & $12.4(9.4-13.9)$ & 5.7 & $15.4(12.9-20.9)$ & $15.2(12.6-20.6)$ \\
\hline Amphiroa spp. & $11.5(9.4-12.8)$ & 19.0 & $11.0(6.4-17.4)$ & $8.1(3.4-12.8)$ \\
\hline Caulerpa spp. & - & - & $0.2(0-1.0)$ & $0.7(0.2-1.6)$ \\
\hline Dictyota spp. & $2.0(0.4-3.4)$ & 1.4 & $15.2(2.7-27.2)$ & $12.0(5.9-22.0)$ \\
\hline Galaxaura spp. & $1.6(1.4-1.7)$ & 1.0 & $1.3(0-3.2)$ & $2.1(0.3-4.0)$ \\
\hline Halimeda spp. & $3.8(2.7-5.3)$ & 8.6 & $0.9(0-2.3)$ & $1.3(0.5-2.0)$ \\
\hline Lobophora variegata & $1.8(0.9-2.9)$ & 6.9 & $0.8(0-2.3)$ & $<0.1(0-0.1)$ \\
\hline Stypopodium zonale & - & - & $1.5(0-3.2)$ & - \\
\hline Turbinaria spp. & - & - & $0.1(0-0.5)$ & - \\
\hline Other frondose algae & $0.2(0.1-0.5)$ & 3.1 & $0.1(0-0.3)$ & $0.3(0-0.6)$ \\
\hline Crustose algae & $8.7(8-10.2)$ & 3.6 & $15.1(10.3-20.1)$ & $5.1(1.8-7.5)$ \\
\hline Total algal cover & $44.7(41.1-47.6)$ & 66.3 & $64.9(54.6-77.8)$ & $45(24.7-71.4)$ \\
\hline Sponges & $4.8(2.2-7)$ & - & $4.7(0.2-11.5)$ & $<0.1(0-0.1)$ \\
\hline Branched Gorgonaceans & $0.2(0-0.7)$ & - & $0.2(0-0.4)$ & - \\
\hline Erythropodium caribaeorum & $0.5(0-.4)$ & - & - & - \\
\hline Palythoa spp. & - & - & $0.2(0-0.7)$ & $0.2(0-1.0)$ \\
\hline Other Anthozoa & $<0.1(0-0.1)$ & - & $0.1(0-0.1)$ & $<0.1(0-0.1)$ \\
\hline Total other groups & $5.5(2.3-7.6)$ & - & $5.1(0.2-11.5)$ & $0.3(0-1.2)$ \\
\hline Bare rock & $0.1(0-0.4)$ & 0.3 & - & - \\
\hline Total & 100 & 100 & 100 & 100 \\
\hline
\end{tabular}

wider (up to $200 \mathrm{~m}$ off Capurganá) and a shallow wave breaking reef crest is even developed. Although the bottom off the coast and within the bays of Capurganá and Sapzurro is predominantly covered by sand, scattered coral heads and patch reefs are found.

The coral-algae dominated community is one of the prevailing marine hard bottom habitats in the area. Cluster analysis of the 12 sample sites segregated at $55 \%$ of similarity three major groups including three or more sample sites and a detached site (Fig. 3). Each group represents a different assemblage of species, and was named according to characteristic coral species and/or the dominant group. Relative cover values of sessile biota in these four assemblages are presented in Table 1 .

The assemblage represented by stations $1,5,7$, and 8 , named 'strigosa-crustose algae', is dominated by scattered encrusting colonies of the scleractinian Diploria strigosa, various crustose red algae (nongeniculate corallines and Peyssonnelia spp.), algal turfs, macroalgae (Dictyota alternans, D. cer- 
vicornis, D. pfaffii, Amphiroa fragilissima, A. hancockii and A. tribulus) and diverse gorgonian octocorals (Muriceopsis flavida, Eunicea spp. Plexaura spp., Pterogorgia anceps, P. citrina, Pseudopterogorgia americana and others). Other hard coral species, as well as diverse sponges and Dictyota were usually present but they seldom attained significant cover values (Table 1). Only the scleractinians Montastraea cavernosa and Porites astreoides may become frequent in deeper, sheltered settings. According to our observations, this is the most widely distributed assemblage in the area. It is developed in depths between 2 and $7 \mathrm{~m}$ on the submarine terrace that fringes almost the entire coast facing to the open sea, and exposed to heavy swells from the north. The scarce scleractinian settlement is dominated merely by incrusting forms, resulting in a weak vertical development of the bottom topography.

Stations 3, 4, 10, and 11 represent a second assemblage. It is named 'siderea' because of the conspicuous dominance of massive, semi-spherical colonies of Siderastrea siderea, which usually grow very close to each other covering nearly $50 \%$ of the bottom area. With the exception of benthic algae (turfs, crustose and macroalgae), other bottom covering organisms, including scleractinians, are sparsely represented. This assemblage occurs in shallow, rather sheltered zones. It is particularly well developed in the interior of the cove of Sapzurro and neighbouring areas (Fig. 4), even forming topographically irregular structures.

An 'Agaricia spp.' assemblage, represented only by station 9 but occurring also in the bay of Capurganá and in the cove of Sapzurro (Figs. 4, 5, and 6), is widely dominated by the lettuce corals Agaricia agaricites and/or A. tenuifolia. Excepting the well developed reef where station 9 was located and a noticeable cover of live coral could be observed (Table 1), other patches of 'Agaricia spp.' were found mostly dead and widely covered by brown algae (mainly Dictyota cervicornis, D. pfaffii and Lobophora variegata), green algae (Halimeda spp.) and blue-green algae. An extensive 'Agaricia spp.'reef is located between the mainland coast and the Terrón de Azúcar. It attains an area of nearly $1 \mathrm{~km}^{2}$

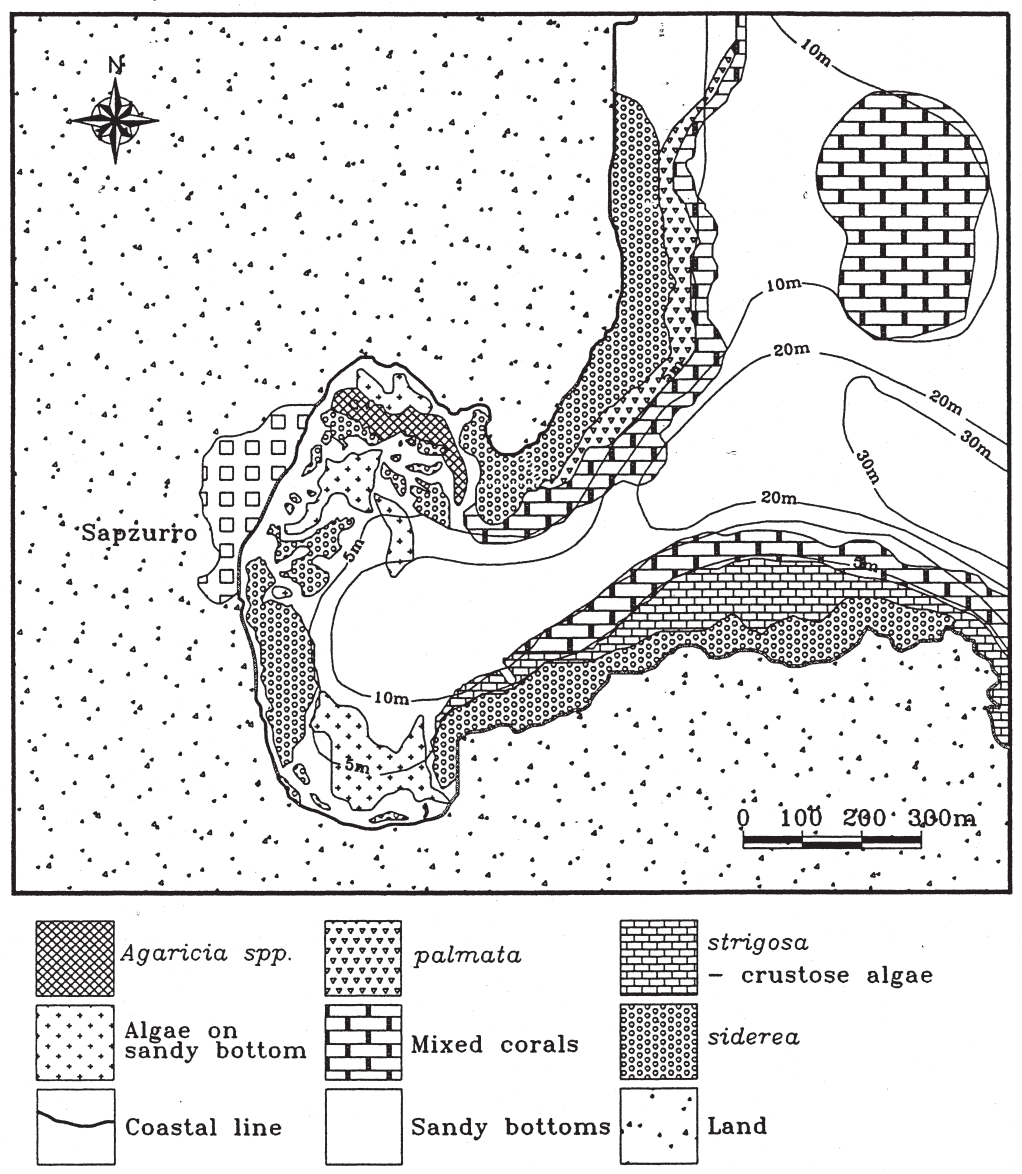

FIG. 4. - Bottom topography and distribution of coral assemblages and other bottom habitats within and off the Cove of Sapzurro. 


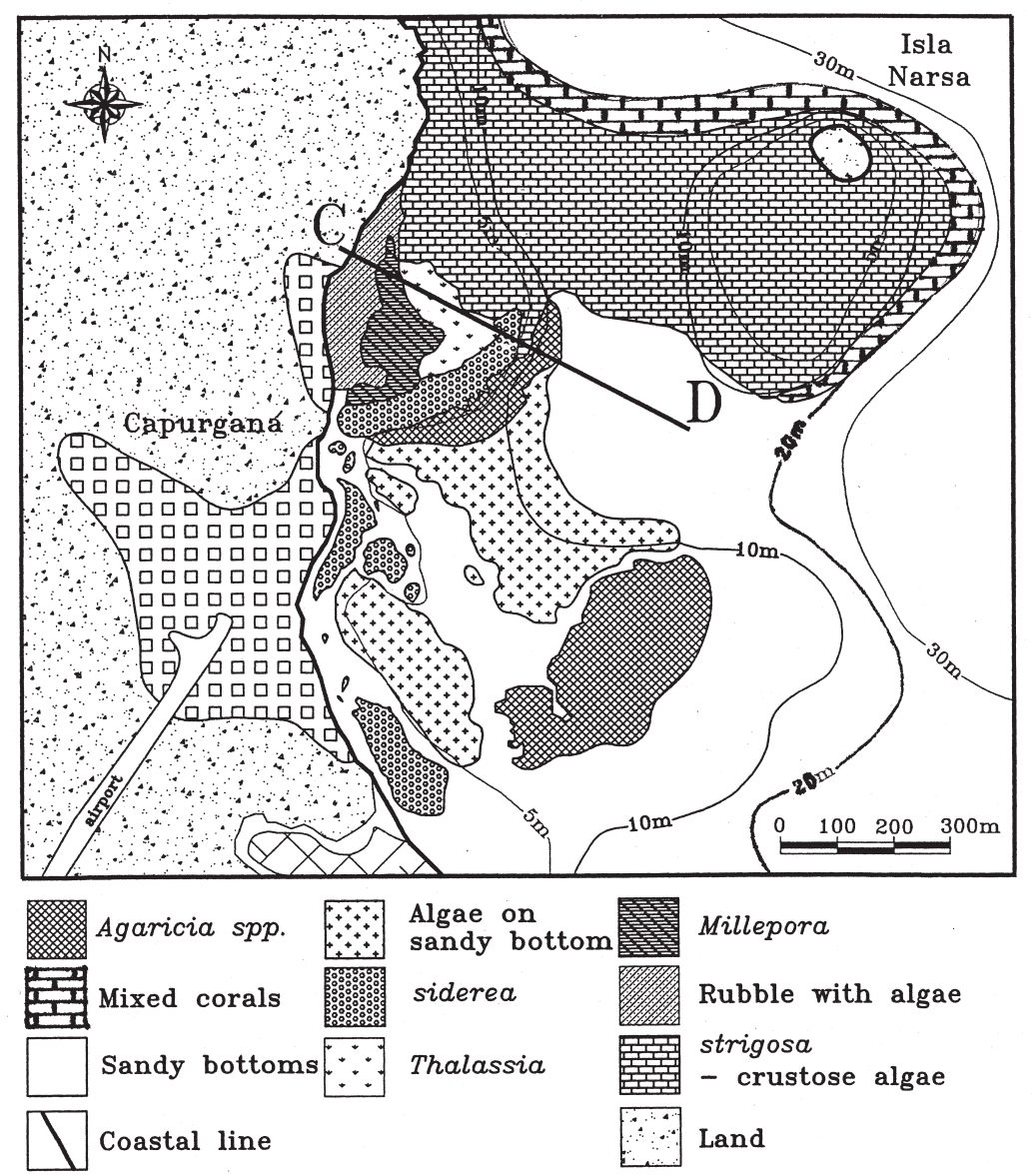

FIG. 5. - Bottom topography and distribution of coral assemblages and other bottom habitats in the bay of Capurganá. Straight line C-D marks the location of the schematic profile of Figure 6.
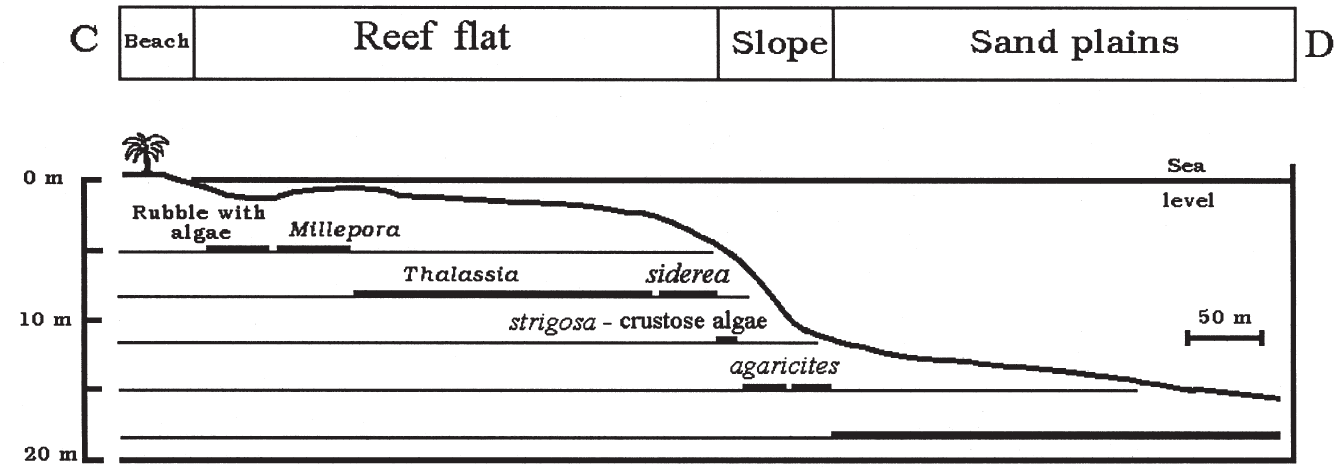

FIG. 6. - Schematic profile (straight line C-D in Fig. 5) showing the zonation of coral assemblages and bottom type habitats in the bay of Capurganá.

and consists of a series of more or less parallel midrelief spurs which are orientated approximately in $\mathrm{N}-\mathrm{S}$ direction, perpendicular to the main wave trend. The width of these structures is variable and some rise up to $7 \mathrm{~m}$ above the basal, sand-covered bottom that lies at depths between 12 and $17 \mathrm{~m}$. (Fig. 7). The main reef builders on the upper part of the buttresses are A. agaricites and A. tenuifolia, but the deeper slopes and basis are predominantly covered by foliose and massive colonies of Colpophyllia natans, Montastraea spp. and Mycetophyllia spp.

The coral assemblage in settings deeper than 10 $m$ was mostly characterized by a dense and diverse scleractinian cover, the 'mixed corals' assemblage. It was recorded by stations 2, 6 and 12, but is seemingly common in this area on deeper, inclined hard 


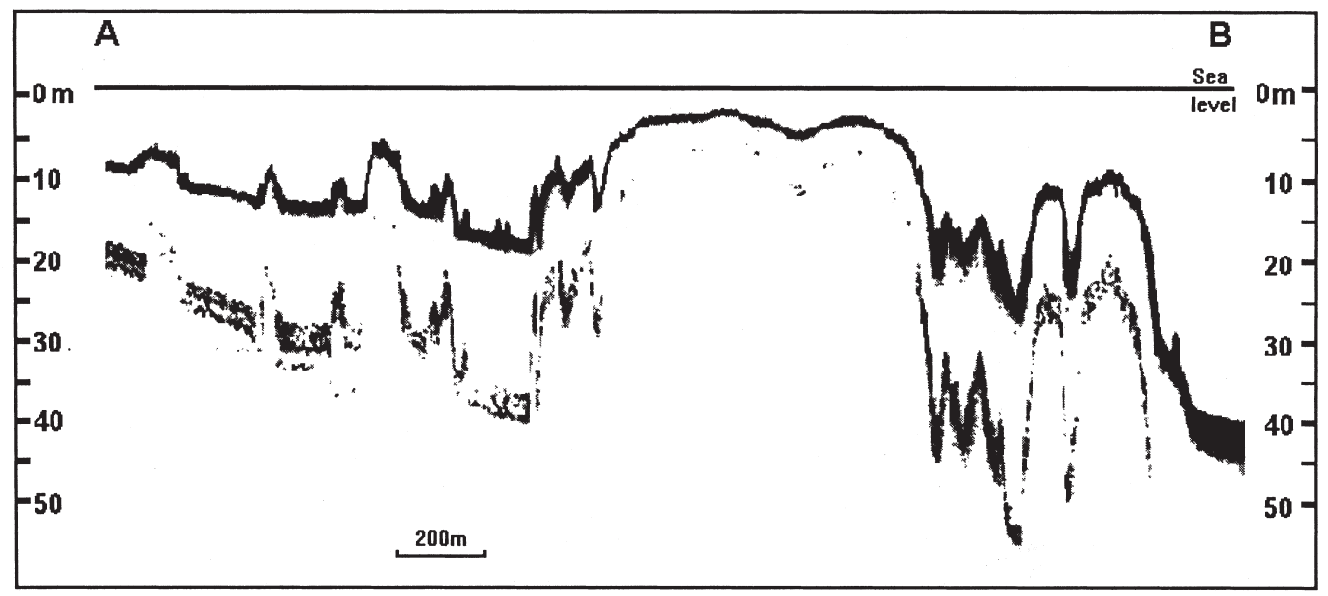

FIG. 7. - Echosounder bathymetric profile across the mid relief spurs between the mainland coast and the islet Terrón de Azúcar (straight line A-B in Fig. 2). The upper parts of the high reliefs in the left half of the profile are covered by the 'Agaricia spp.' assemblage, the deeper ones by the 'mixed corals' assemblage.

bottoms and relatively well-illuminated waters. Massive and plate-like forms of the scleractinians Montastraea cavernosa, M. franksi, Colpophyllia natans and Agaricia agaricites were generally predominant, but other stony corals, sponges, gorgonians, macroalgae and crustose algae were usually well represented as well.

Further two minor coral-dominated communities were observed, although none of them were quantitatively recorded by any station. A narrow 'palmata'-zone was apparent in several settings between the 'strigosa-crustose algae' and the 'mixed corals' zones, such as nearby stations 5 and 6 . Here, medium-sized, mostly dead thickets of the branching scleractinian Acropora palmata form a series of low, elongated spurs that are predominantly oriented perpendicular to the reef front. Algal turfs, scattered encrusting colonies of $D$. strigosa, the hydrocoral Millepora complanata and sheet-like encrusting sponges (Cliona spp.) overgrow usually the dead thickets of Acropora. Furthermore, a small but conspicuous 'Millepora-zone' occurs on the shallowest, innermost part of the reef flat off Capurganá (Figs. 5 and 6). The waves approaching the coast break constantly in this area, creating a rather turbulent environment. The hydrocoral $M$. complanata, which is here commonly associated with encrusting coralline algae, the green alga Halimeda opuntia, the finger coral Porites furcata, and the turtle grass (Thalassia testudinum) form a distinctive assemblage.

A total of 31 scleractinian, two milleporinid and one stylasterinid coral species were recorded during our survey (Table 2). Of them, 21 were registered in the transects, while 13 were sighted during recon-
TABLE 2. - Coral species registered in this study in the NW part of the Golfo de Urabá. Species marked with * are new records for this area.

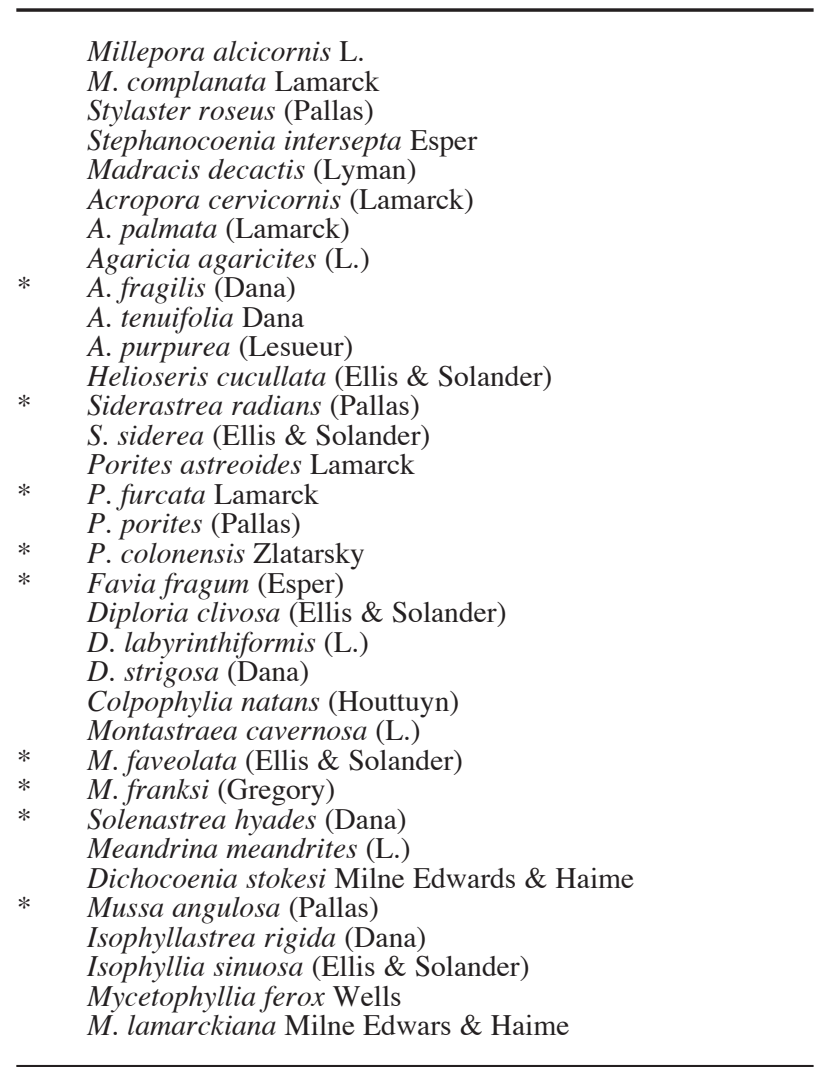

naissance dives. Numbers of coral species in the study area tend seemingly to increase towards NW, in fact the most diverse sector was near the entrance to the cove of Sapzurro with 28 coral species, while in all sites visited between Terrón de Azúcar and Capurganá 21 species were recorded. 
Living coral cover (relative to hard substrate) on the 12 sites visited for quantitative estimations ranged from $22 \%$ to $69 \%$ (average: $44.6 \%$, see Table 1). Several sites exhibited very scarce living coral tissue cover. This was particularly apparent for reef zones supposedly corresponding to the 'Agaricia spp.' assemblage. There, the upright, leaf-like colonies of A. tenuifolia were mostly dead and largely covered by foliose macroalgae, such as Lobophora variegata, Dictyota spp., Halimeda opuntia and by blue-green algae. Settings corresponding to the 'palmata' zone mostly exhibited very scarce cover of living coral as well. Although large thickets of $A$. palmata were still standing, only small and scattered portions of them displayed living tissue and were largely dominated by algal turfs.

\section{DISCUSSION}

With the exception of a few low-lying, isolated offshore patch reefs, the modern coral communities and framework structures of the northwestern part of the Golfo de Urabá are typically of the fringing type. At present, their southernmost occurrence is at about $8^{\circ} 35^{\prime} \mathrm{N}$, nearly $12 \mathrm{~km}$ southeastward of the Colombia-Panama border at Cabo Tiburón. The development of coral framework in this area seems likely to have taken place under sub-optimal water conditions due to considerable amounts of sediment and freshwater discharged by the Atrato River and other streams (Zeigler and Athearn, 1971). In general terms, reef development, coral diversity and live coral cover increase along the coast in a SE-NW direction, seemingly following an overall improvement of conditions for coral growth and settlement in that direction.

Although sparse coral carpets made up mostly by encrusting scleractinians, crustose algae and gorgonians represent the commonest shallow-water habitat in this area, a diverse hermatypic biota has developed in several places. Most of these reefs rise several meters above the basal, generally sand-covered bottom, and seem likely to overlay older limestone. Wave-cut notches at a depth of about $8 \mathrm{~m}$ insinuate in places where subvertical reef slopes occur, like nearby stations 10 and 11, denoting an earlier sea level stand. Moreover, Holocene uplifted reefs with rich sub-fossil scleractinian and molluscan faunas form an elevated, wave-cut littoral terrace at about $1 \mathrm{~m}$ above present sea level in the southern part of the study area extending as far as to the village of Acandí at $8^{\circ} 32^{\prime} \mathrm{N}$ (Werding and Manjarrés, 1978). Hence, neotectonic activity appears to have played an important role controlling the morphology and spatial distribution of coral communities along the northwestern coast of the Golfo de Urabá. The uplift of the coast is apparently continuing today as evidenced by the fact that the area is out of isostatic equilibrium (Case et al., 1990).

Besides substrate availability, the main factors controlling the zonation and distribution patterns of the six major types of scleractinian assemblages in the area are wave-energy (turbulence of water and abrasion), light penetration (as a function of depth and water turbidity) and bottom topography. The classical scheme of zonal structure of Caribbean coral reefs according to wave zones (Geister, 1977, 1983) applies well to oceanic reefs without significant influence of terrestrial runoff. However, stress caused by terrigenous sediments and salinity in continental reefs may modify the vertical distribution, composition and dominance of certain coral species (Muthiga and Szmant, 1987; Acevedo et al., 1989). Thus, highly efficient suspension feeders such as Siderastrea siderea and Diploria strigosa (Lewis, 1976), which are particularly resistant to sediment fall (Budd et al., 1993), and Agaricia tenuifolia which is well adapted to low light penetration (Acevedo et al., 1989), are characteristic species in three of the six scleractinian assemblages recognized.

The 'strigosa-crustose algae' assemblage is characteristic for the wave-exposed, turbulent settings in the shallow submarine terrace that borders the active coastal cliff. Such bare hard grounds that are partially covered by incrusting scleractinians (such as Diploria strigosa), crustose algae and branching, flexible gorgonians constitute a characteristic association in coastal terraces under the influence of periodic abrasion caused by storm waves elsewhere in the Caribbean (Geister, 1983). The intensity of abrasion on this terrace decreases gradually towards the sea, and therefore the relative bottom cover of other organisms, including massive and branching scleractinians (Acropora palmata, Porites astreoides, Montastraea spp.) and foliose macroalgae, becomes more important. The transition to other scleractinian assemblages occurring in deeper, less abrasive or turbulent waters, is usually given at depths between 5 and $10 \mathrm{~m}$, depending on the steepness of the slope. On the gently dipping coastal terrace, the sequence to the 'mixed corals'-assemblage is usually very gradual 
over other assemblages such as 'palmata' and/or 'siderea'. On the other hand, where a steep slope truncates the outer margin of the terrace, the 'Agaricia spp.' assemblage monopolizes the bottom community. The species of Agaricia, especially A. tenuifolia, grow fairly well in poorly illuminated zones and their planula larvae seem preferably to settle in dark places of the reef (Lewis, 1974), like those prevailing in steep slopes (see also Geister, 1983: 223).

In their earlier works, neither Werding and Manjarrés (1978) nor Prahl and Erhardt (1985) made any statements about evidence of coral mortality or overgrowth by algae. Notwithstanding, declines and overgrowth by blue-green algae of some live coral species, in particular Agaricia, on the reefs of the Golfo de Urabá were observed. Although not all corals showed unequivocal signs of decline, foliose and branching corals appear to be particularly affected.

Agaricia spp. evidently constituted formerly dense patch reefs and covered the steep slopes of reefs in sheltered settings within the bays of Capurganá and Sapzurro. During our survey, most of the Agaricia spp., especially A. tenuifolia, were found dead and their skeletons overgrown by the brown algae Lobophora variegata and Dictyota spp. In some cases where dense algal mats were pulled away white skeletons of recently dead colonies were observed. The corals A. tenuifolia and A. agaricites have been recorded as the most affected by recent coral mortality in the reefs of the nearby San Blas Islands in Panama (Ogden and Ogden, 1994; Shulman and Robertson, 1996) as well as in most reef areas off the Colombian Caribbean coast (GarzónFerreira and Kielman, 1994; Díaz et al., 1996c). Agaricia was severely impacted by bleaching episodes during the 1980's in Panama (Shulman and Robertson, 1996) and Colombia (Lang, 1987) and it seems to be particularly susceptible to macroalgal overgrowth (Shulman and Robertson, 1996).

Extensive debris fields of Acropora cervicornis were found during our survey but only a few, small living thickets of this species could be seen. A. cervicornis usually takes up a definite wave zone in Caribbean coral reefs (Geister, 1977, 1983) but it has declined in much of the Caribbean over the past three decades (Smith and Ogden, 1994; Zea et al., 1998). This might be the reason why a characteristic 'cervicornis' assemblage, that should be expected between the 'palmata' and the 'mixed corals' assemblages, could not be recognized in this study.
A similar but less startling case is that of A. palma$t a$. White band disease and bleaching events were the most likely causes of massive die-offs of Acropora spp. in Panama (Ogden and Ogden, 1994; Shulman and Robertson, 1996), Colombia (Solano et al., 1993; Garzón-Ferreira and Kielman, 1994) and elsewhere in the Caribbean (Smith and Ogden, 1994).

The coral reefs in the area are well developed down to a maximum depth of about $18 \mathrm{~m}$, and comprise a total of 33 hard coral species, which represents about $64 \%$ of the total diversity of hard corals known for the Colombian Caribbean (cf. Prahl and Erhardt, 1985). With regard to the previously reported coral taxa in this area (checklists in Werding and Manjarrés, 1978 and Prahl and Erhardt, 1985), six out of 33 hard coral species registered in our survey are unequivocally recorded for the first time (Table 2). On the other hand, taxa in the pre-existing checklist that were definitely not registered during our survey are Agaricia lamarcki, Montastraea annularis (s.s.), Manicina areolata, Mycetophyllia aliciae, Scolymia lacera, and Eusmillia fastigiata. Further discrepancies between both inventories result either from synonymy (Stephanocoenia michelini $=S$. intersepta) and splitting of former taxa (Montastraea annularis in M. annularis s.s., M. faveolata and $M$. franksi) or seem likely related to taxonomic misidentifications (Millepora squarrosa for $M$. complanata and Isophyllia multiflora for I. sinu$o s a$ ). In any case, the number of coral species occurring in the area (at least 36 species, or $70 \%$ of the hard corals known for the Colombian Caribbean) is a considerable amount for a region in which natural conditions may be regarded as suboptimal for reef development and coral settlement. Recorded numbers of hermatypic coral species in other well known reef areas in Caribbean Panama, (e.g. 35 at Galeta Island, Porter, 1972; 33 at Bocas del Toro, Guzmán and Guevara, 1998) and Colombia (e.g. 18 at Bahía Portete, Solano, 1994; 27 at Isla Fuerte, Díaz et al., 1996), where rather turbid and/or low salinity conditions predominate as well, are similar or even lower.

The vertical zonation and dominance of certain coral species in the assemblages described above (e.g. Siderastrea siderea, Agaricia tenuifolia, Diploria strigosa) suggest that these assemblages developed by adapting gradually to low salinity and high turbidity conditions, actually limiting a more robust development of reef framework and a more diverse community. 


\section{ACKNOWLEDGEMENTS}

We thank Jaime Garzón-Ferreira, Luz S. Mejía and the crew of the R/V Ancón for their invaluable assistance with fieldwork. We also thank Sven Zea for field assistance and helpful discussions. This study was supported by the Instituto Colombiano para el Desarrollo la Ciencia y la Tecnología, COLCIENCIAS (Grants No. 2105-09-023-93 and 210509-120-97) and the Instituto de Investigaciones Marinas y Costeras, INVEMAR. This is contribution No. 636 of INVEMAR.

\section{REFERENCES}

Acero, A. and J. Garzón. - 1987. Los peces marinos hallados durante la expedición Urabá II al Caribe chocoano (Colombia). An. Inst. Invest. Mar. Punta de Betín, 17: 113-136.

Acevedo, R., J. Morelock and R.A. Olivieri. - 1989. Modification of coral reef zonation by terrigenous sediment stress. Palaios, 4: $92-100$.

Budd , A.F., K.O. Mann and H.M. Guzmán. - 1993. Environmental interpretation using insoluble residues within reef coral skeletons: problems, pitfalls, and preliminary results. Coral Reefs, 12(1): 31-42

Bula-Meyer, G. and R. Schnetter. - 1988. Las macroalgas recolectadas durante la expedición Urabá II, costa caribe del noroeste chocoano, Colombia. Bol. Ecotrópica, 18: 19-32.

Campos, N.H. and G. Manjarrés. - 1988. Decápodos Brachyura de la región noroccidental del Golfo de Urabá (Caribe colombiano). An. Inst. Invest. Mar. Punta de Betín, 18: 17-24.

Case, J.E., W.D. MacDonald and P.J. Fox. - 1990. Caribbean crustal provinces: Seismic and gravity evidence. In: G. Deugo and J.E. Case (eds.), The Caribbean Region, The Geology of North America, Vol. H. Geological Society of North America, Boulder, Colorado, USA

Coates, A.G. and J.A. Obando. - 1996. The geologic evolution of the Central American Isthmus. In: J.B.C. Jackson, A.F. Budd and A.G. Coates (eds.), Evolution and environment in tropical America, pp. 21-56. University of Chicago Press, Chicago \& London.

Díaz, J.M., J.A. Sánchez, S. Zea and J. Garzón-Ferreira. - 1996. Morphology and marine habitats of two southwestern Caribbean atolls: Albuquerque and Courtown. Atoll Res. Bull., 435: $1-33$.

Díaz, J.M., G. Díaz-Pulido, J. Garzón-Ferreira, J. Geister, J.A. Sánchez and S. Zea. - 1996. Atlas de los arrecifes coralinos del Caribe colombiano, I: Complejos arrecifales oceánicos. INVEMAR, Publicación Especial No. 2, Santa Marta, 83 p.

Díaz, J.M. J.A. Sánchez and G. Díaz-Pulido. - 1996. Geomorfología y formaciones arrecifales recientes de Isla Fuerte y Bajo Bushnell, plataforma continental del Caribe colombiano. Bol. Invest. Mar. Cost., 25: 87-105.

Duque-Caro, H. - 1990. Neogene stratigraphy, paleoceanography, and paleobiology in northwest South America and the evolution of the Panama Seaway. Palaeogeogr. Palaeoclimatol. Palaeoecol., 77: 203-234.

Duyl, L.F. - 1985. Atlas of the living reefs of Curacao and Bonaire (Netherlands Antilles). Natuurwetenshappeliijke Studiekring Suriname \& Ned. Antilles, Utrecht..

Garzón-Ferreira, J. and M. Kielman. - 1994. Extensive mortality of corals in the Colombian Caribbean during the last two decades. In: R. N. Ginsburg (Compiler), Proceedings of the Colloquium on Global Aspects of Coral Reefs: Health, Hazards and History, 1993, pp. 247-253. Rosenstiel School of Marine and Atmospheric Science, Univ. of Miami.

Geister, J. - 1977. The influence of wave exposure on the ecological zonation of Caribbean coral reefs. Proc. $3^{\text {th }}$ Int. Coral reef Symp., Miami, 1: 23-29.
Geister, J. - 1983. Holozäne westindische Korallenriffe: Geomorphologie, ökologie und Fazies. Facies, 9: 173-284.

Gentry, A.H. - 1986. Species richness and floristic composition of Choco region plant communities. Caldasia, 15(71-75): 71-79.

Guzmán, H.M. and C.A. Guevara. - 1998. Arrecifes coralinos de Bocas del Toro, Panamá: I. Distribución, estructura y estado de conservación de los arrecifes continentales de la Laguna de Chiriquí y la Bahía Almirante. Rev. Biol. Trop., 46(3): 601-623.

Haffer, J. - 1970. Geologic-climatic history and zoogeographic significance of the Uraba Region in northwestern Colombia. Caldasia, 10(50): 603-636.

Lang, J.C. - 1987. The 1987 bleaching event at Islas del Rosario. Unpubl. Report, INDERENA and Univ. of Texas, Austin, 23 p.

Lewis, J.B. - 1974. Settlement and growth factors influencing the contagious distribution of some Atlantic reef corals. Proc. $2^{\text {th }}$ Int. Coral Reef Symp., Australia: 201-206.

Lewis, J.B. - 1976. Experimental tests of suspension feeding in Atlantic reef corals. Mar. Biol., 36: 147-150.

Muthiga, A.N. and A.M. Szmant. - 1987. The effects of salinity stress on the rates of aerobic respiration and photosynthesis in the hermatypic coral Siderastrea siderea. Biol. Bull., 173: 539-551.

Ogden, J. C. and N. B. Ogden. - 1994. The coral reefs of the San Blas Islands: Revisited after 20 years. In: R. N. Ginsburg (Compiler), Proceedings of the Colloquium on Global Aspects of Coral Reefs: Health, Hazards and History, 1993, pp. 267-272. Rosenstiel School of Marine and Atmospheric Science, Univ. of Miami.

Porter, J.W. - 1972. Ecology and species diversity of coral reefs on opposite sides of the Isthmus of Panama. Bull. Biol. Soc. Wash., 2: 89-116.

Prahl, H. v. and H. Erhardt. - 1985. Colombia, Corales y Arrecifes Coralinos. Fondo para la Protección del Medio Ambiente "José Celestino Mutis", Bogotá.

Sánchez, J.A. - 1995. Benthic communities and geomorphology of the Tesoro Island reef, Colombian Caribbean. An. Inst. Invest. Mar. Punta Betín, 24: 55-77.

Sánchez, J.A. and V. Ortiz. - 1992. Distribución de los corales negros (Antipatharia, Antipathidae) de arrecifes coralinos entre Cartagena y el Golfo de Urabá, Caribe colombiano. Mem. VIII Semin. Cienc. Tecnol. Mar, CCO, Bogotá, 1: 362-369.

Shulman, M.J. and D.R. Robertson. - 1996. Changes in the coral reefs of San Blas, Caribbean Panama: 1983 to 1990. Coral Reefs, 15(4): 231-236.

Smith, S.R. and J.C. Ogden (eds.). - 1994. Status and recent history of reefs at the CARICOMP network of Caribbean marine laboratories. In: R. N. Ginsburg (Compiler), Proceedings of the Colloquium on Global Aspects of Coral Reefs: Health, Hazards and History, 1993, pp. 73-79. Rosenstiel School of Marine and Atmospheric Science, Univ. of Miami.

Solano, O.D. - 1994. Corales, formaciones arrecifales y blanqueamiento de 1987 en Bahía Portete (Guajira, Colombia). An.Inst. Invest. Mar. Punta Betín, 23: 149-164.

Solano, O.D., G. R. Navas and S.K. Moreno-Forero. - 1993. Blanqueamiento coralino de 1990 en el Parque Nacional Natural Corales del Rosario (Caribe colombiano). An. Inst. Invest. Mar. Punta Betín, 22: 97-111.

Wells, S. - 1988. Coral reefs of the world. Vol. 1: Atlantic and eastern Pacific. UNEP Regional Seas Directories and Bibliographies, IUCN, Gland, Switzerland.

Werding, B. - 1978. Los porcelánidos (Crustacea: Anomura: Porcellanidae) de la región de Acandí (Golfo de Urabá), con algunos encuentros nuevos de la región de Santa Marta (Colombia). An. Inst. Invest. Mar. Punta de Betín, 10: 213-222.

Werding, B. and G. Manjarrés. - 1978. Informe sobre las estructuras litorales y la flora y fauna marina en el nor-oeste del Golfo de Urabá. Instituto de Investigaciones Marinas de Punta de Betin, INVEMAR, unpubl. rep., 85 p.

Zea, S., J. Geister, J. Garzón-Ferreira and J.M. Díaz. - 1998. Biotic changes in the reef complex of San Andrés Island recorded over three decades (southwestern Caribbean, Colombia). Atoll Res. Bull., 456: 1-30.

Zeigler, J.M. and W.D. Athearn. - 1971. The hydrography and sediments of the Gulf of Darien. Mem. $4^{\text {th }}$ Carib. Geol. Conf., Trinidad, 1965: 335-341.

Scient. ed.: J.M. Gili 